\title{
Sex, gender, and marriage in the timber plantations of KwaZulu-Natal, South Africa: a minor otherwise
}

\author{
Thomas Cousins* \\ Department of Sociology and Social Anthropology, Stellenbosch University, Stellenbosch, South \\ Africa
}

In this article, I describe the practice of a "game" of marriage between women labourers in the timber plantations of KwaZulu-Natal, South Africa, called umshado wokudlala. I describe the ritualised game in order to follow the ways in which kin terms operated in daily usage among the labourers. Umshado wokudlala shows how a form of "play" opens out and re-imagines possibilities for organising care, intimacy, and relatedness under conditions of late capitalism. I suggest that the use of kin terms in this "game" indexes shifting material conditions for mutuality, intimacy, and relatedness, and thus reveals the qualities of kinship, sex, and gender as systems of signs tethered to the material conditions that make possible language-in-use. If anthropology understands kin terms to be laminated onto systems of gender, kinship, and sex, it is because it is the dominant mode through which it understands life. I have sought to show that the modalities of comprehending obligation, relatedness and reproduction undergo a degree of "torsion" in the practices and utterances of the game's participants, and that securing their meanings and referents is a much trickier affair than many accounts of marriage would have us believe.

Keywords: sex-gender system; kinship; language; play

In 2009, one of the two largest paper and pulp corporations in South Africa began implementing a nutrition intervention as part of a suite of labour reforms aimed at improving working conditions among 10,000 contracted labourers in its timber plantations. By tracking the nutrition intervention during 2009, and the delivery of carefully calculated calories to specific groups of people in remote timber plantation compartments, I began to understand something of the effort and imagination required to stay alive under numbing conditions of labour (Cousins 2014). The people who work in the timber plantations must contend with a range of forces that splinter the effort to remain human: the fragmentation of spaces of habitation; the extraction of every ounce of labour power from the body; the wasting of the body by disease; the combined effects of many decades of impoverishment; and the erosion of trust, intimacy, and familiar modes of obligation and reciprocity.

Amongst the unnaturally straight lines of trees, or along the side of the road, women who labour in the timber plantations (and in other plantations and agricultural settings in northern KwaZulu-Natal) play a game that they call umshado wokudlala: a game of marriage, or play marriage. In this article, I describe the ritualised game in order to follow the ways in which kin terms operated in daily usage among the labourers. After one year of ethnographic fieldwork in and around the timber plantations, I came to see how a form of "play" opens out and re-imagines possibilities for organising care, intimacy, and relatedness under conditions of late capitalism. Here I suggest that the use of kin terms in this "game" indexes shifting material conditions for mutuality, intimacy, and relatedness, and thus reveals the qualities of kinship, sex, and gender as systems of signs tethered to the material conditions that make possible language-in-use.

By tracking the various ways in which kin terms and ritual forms were used and described, it is possible to see how they open out, rather than close or fix, the possibilities for constituting care, intimacy, and relatedness. Possible inflections of umshado wokudlala include game of marriage, sham-marriage, or playing-at-marrying. However, learning the meaning of

"Email: tcousins@sun.ac.za 
this term requires some sense of language in action and the projections that define its usage. An anthropological rendering of the term would suggest that it is a practice that celebrates affectionate relations among women by riffing on customary marriage practices. Here I describe the ritual events that define umshado wokudlala, and analyse the commentary on these marriages by three timber plantation labourers who participated in them.

By naming and describing the elements of what my interlocutors called a "game," I seek to parse out some of what Michael Silverstein and scholars of metapragmatics call the "presuppositions" of the ritual moment: that is, the various texts, traditions, and trials that are indexed by the gestures and utterances of the participants as they bring kin terms and affections into new relations (Silverstein 1993, 1997; Urban 2001). How best to think about the "entailments" of such a game is less clear, but equally important, given the violence surrounding non-normative sexualities in contemporary South Africa. Recent literature on language, sex, and gender in South Africa has begun to unpack a range of questions concerning the ways in which sexuality and marriage might be rethought in more explicitly queer terms in post-apartheid South Africa (Milani 2015; Msibi and Rudwick 2015). In drawing on linguistic analyses of kinship which show how sign vehicles are stitched to their contexts of use, I seek to amplify the interpretive possibilities for thinking about how care, intimacy, and relatedness are constituted (Agha 2007; Silverstein 2003).

\section{Unnatural histories of sex, gender, and kinship in South Africa}

Since the earliest anthropological and missionary reports on the processual nature of African "marriage," colonial administrations in South Africa struggled to specify criteria for what constituted a "customary union." The recognition of Native Law in 1848, followed by the "Kafir Commission" of 1852-1853, which sought to outlaw polygamy and ilobolo in pursuit of a more "civil" approach to the administration of native affairs, and the formalisation of customary union under the Shepstone system with the promulgation of the "New Marriage Regulations and Fees of 1869," were critical moments in the stabilisation of an object of colonial scandal (McClendon 2010). ${ }^{1}$ In their concern with grasping the minimal criteria of marriage and the adjudication of property, early twentieth-century colonial legal and administrative texts produced a naturalised assemblage of terms such as bride, wedding, ritual, ancestors, and religion. Through the exercise of law, the customary - and in particular, "customary union" - took shape alongside a picture of who was party to the exchanges, the nature of their consent, the "attitudes" appropriate to the event, and the property that was exchanged. ${ }^{2}$ However, a more critical return to that archive would suggest that the "natural history" of customary marriage in South Africa contains within it a queer possibility amplified in many contemporary social projects, umshado wokudlala being one of them (by project I mean the sense of making social worlds otherwise, well described by Elizabeth Povinelli 2011; see also McCormick 2015; Boellstorff and Dave 2015).

One example of that queer possibility is Gluckman's 1950 analysis of Lozi and Zulu marriage, which is significant because it was the first to produce a typology of marriage that could be applied comparatively across African contexts (cf. Radcliffe-Brown and Forde 1950). In borrowing Evans-Pritchard's terms for Nuer marriage, ${ }^{3}$ Gluckman describes seven types of family formed by marriage that establishes an early ethnographic record of the disarticulation between sex, gender, and kinship. Gluckman relies on the difference between descriptive and classificatory kin terms to render the distinction between pater and genitor as a structural figuration of attitudes and norms concerning legitimate reproduction. ${ }^{4}$ The grid of descriptive/classificatory terms and the resulting norms of affection resulting from their structural functional relations were thus foundational, in the sense of grounding a picture of social relations, to the analysis of kinship and marriage as naturalised expressions of social structure. These seven forms of marriage, Gluckman maintained, all depend on the legal consequences that flow from the cattle that a Zulu man gives for his bride. " "The cattle make him pater of all her children, whether or not he is their genitor" (Gluckman 1950, 184). Thus, because 
"classificatory kinship" diverges from the facts of biology, the institutionalised figure of the pater, who can be male or female, dead or alive, singular or plural, ${ }^{6}$ allows for the structural reproduction of the lineage to disconnect from biologised or fixed relations of gender. ${ }^{7}$ Although Gluckman did not take forward the performative implications of such a gesture, merely noting the structural movement of kin terms, the analytics thus rested on the action of the transfer of cattle - a gesture conditioned by "custom" and colonial law.

Here I wish to highlight the importance of gesture, words, and situational context to questions of who is doing the marrying (where "doing" might be understood to involve particular utterances, gestures, and settings), what is consented to, and the possibility of (partially) successful performance. ${ }^{8}$ To learn what these terms mean is to enter particular scenes of instruction in which the terms, values, and possibilities for use might turn out to be different from what these "rules" might lead one to expect. Thus the ethnographic archive appears to contain within it a suggestion that questions of paternity, maternity, and lineal reproduction might hinge on a set of performative criteria. Indeed, a substantial archive on "woman-woman marriage" in Africa confirms this notion, the critical feature of such marriages being the payment of "bride-price" to acquire a husband's rights to another woman in juridically sensible terms. As Carrier and Murray (1998) and O'Brien (1977) note, more than 30 groups around Africa, and at least nine Bantu-speaking groups in southern Africa, are described as having some type of female husband. Many of the examples cited are taken as evidence of how African patrilineal descent accommodated alternative figurations of the relationship between sex, gender, and kinship (e.g. Oboler 1980).

While these examples extend patrilineal descent, the cases described by John Blacking (1959, 1978) and Judith Gay (1986) suggest a different direction altogether. Both cases involve young women in boarding schools. The first, John Blacking's description of Venda girls' "play" at high schools in the 1950s, sits in contrast to the "traditional initiation schools" for young girls. The two institutional modes mirror each other as much as they mark off two domains: the "modern" school with its "European" sensibility, replete with "sophisticated" love-letters in English, passionate jealousies, and scope for individual choice and taste, and its "traditional" counterpart that readies young women for customary marriage. The second case (Gay 1986) describes "mummy-baby" relationships at rural high schools in Lesotho in the late 1970s. Gay's analysis points to the possibility that the game served as an education into the roles available for women during the period of high apartheid: "western" high schools were a space in which desire and choice were mapped out in new ways for women, opening on the one hand the possibility of love and romance for modern subjects about to enter urbane South Africa; and on the other, preparation for the imminent feminisation of the labour force across southern Africa, reshaping the contours of (heterosexual) love and companionship.

Where Blacking's and Gay's descriptions are of women in educational settings at particular moments in the gendered history of labour migration, the women in the timber plantations play at umshado wokudlala labour in a regime that has been feminised and redomesticated since the early 1990s: that is, where workers once lived in barracks within the plantations, cared for by the timber companies which directly employed them, they now live "at home" on the edges of the plantations (Pons-Vignon and Anseeuw 2009). ${ }^{9}$ Thus the relationships between plantation workers are layered not only by the many hours spent toiling together, the sweat of which does not entirely secure the well-being of body or family, but also by the locally woven threads of solidarity comprised, most directly and frequently, of mother-daughter dyads, clan affiliation, neighbourly familiarity, generational codes of respect, and customary authority.

While the ethnographic archive contains within it a long record of normative assumptions about the relationship between gender and kinship, it also shows how kin terms do not necessarily correspond with sex-gender systems (Rubin 1975). In their essay on gender and kinship, Yanagisako and Collier (1987) suggested that feminist critiques of the social construction of gender left the supposedly biological fact of sex unexamined. Similar to the way 
in which David Schneider (1968) showed how anthropology took for granted the supposed difference between classificatory and descriptive kinship, thereby assuming a biological basis for descriptive kin, Yanagisako and Collier suggested that anthropology had dragged the residue of a Euro-American folk system into feminist critiques of gender. They argued instead for a unified approach to the study of gender and kinship that would show that they arise together through practices of meaning making and the historical dynamism of "social wholes" within particular matrices of power. I suggest, however, that umshado wokudlala shows that the relations between kinship, gender, and sex do not follow on from each other in any necessary fashion. Rather, they index shifting conditions of possibility for using kin terms and constituting care, intimacy and relatedness.

\section{First event}

The first event I participated in took place in late October 2009, at which two of my friends from the plantations staged a ceremony which they called $u$ kuqoma ${ }^{10}$ on the side of the road on the way back home to Mfekayi, after a day of backbreaking labour. Stopping the transport trucks in the middle of a four-way intersection, and avoiding the sanctioned terrain of the homestead, the women constituted the ritual moment through words, steps, gestures, songs, and gifts, each repurposing the elements of heteronormal customary Zulu marriage. The labourers formed two groups, those of the family to the insizwa, or young man, and those of the intombi, or young girl, the "bride." The bride and her family retreated up the road, to appear 15 minutes later. Nomvula and Zifikele, ${ }^{11}$ the couple in question, worked in different teams within the Nyalazi timber plantation. The men ${ }^{12}$ stood to one side, amused, knowing what was to come, and that this was not their business. This was a game that only women working in the forests played.

The women were all wearing their work clothes: heavy gumboots, standard-issue blue overalls with Njojo, the name of the contractor printed on the back, with a skirt, either long or short, over the pants, and a head cloth, hat or "beanie," 13 faces painted with the usual red ochre to protect from sun-burn, and a grass basket with a few things for the day - water, food, or an extra jersey. The "young man" and her "family" gathered on the ground to the right, sitting in the appropriate way that men sit, some with their legs drawn up and splayed as men do, others on their haunches, as joy and humour set in, and the cry of "insizwa!" went up, collecting all the family of the young man who already had girlfriends, or izintombi. One woman ran out with a knobkerrie, waving and dancing with it in a stylised masculine form. Men ${ }^{14}$ standing on the periphery laughed at the sight of such gendered performances so flawlessly executed by these young "men." By tracking the various role inhabitants and their gestures, utterances, and physical positions within the ritual space constructed on the side of the road, we can begin to trace the referents, signs, and texts aligned against the grain of conventions of Zulu customary marriage.

Izinsizwa each took a turn to dart out off the ground to perform an impressive turn on the road of a particularly high leg throw or sexy hip thrust, as men are supposed to (but which women also do), singing the songs that would normally be sung for ukuqoma, accompanied by strenuous dancing. The approaching party of intombi and her family was announced with ululations and a dizzy distribution of cheap sweets for which the crowd playfully jostled, until the bridal party arrived and gathered in a half-circle in front of the seated men to present their gifts. These were all gifts that Zifikile as intombi had bought for this event, and her friends, standing as family, each came forward to present them to Nomvula, insizwa, who was sitting in the centre of the round. Tea trays, plates, bowls, glasses, teapots, spoons, washbasins and toiletries were all opened and appreciated. Nomvula herself had to be instructed how to sit like a man, with knees drawn up, crotch open, and arms resting on knees. As Nomvula's age-cohort corrected each other on the appropriate way to display the gifts, they addressed each other as "bhuti" (brother). 
Next came a plastic washbasin and a green towel that was thrown around Nomvula's back with the words "I love you" stitched into it; a pink face cloth draped over her shoulder; and a mirror for putting on make-up. ${ }^{15}$ Nomvula untied an orange scarf from her neck and tossed it roughly aside in an aggressive display of masculinity. A member of the intombi's party took from the washbasin a series of toiletries, showing them to the groom before replacing them: a comb, toothpaste, deodorant spray, and camphor cream, which she rubbed onto the groom's face to demonstrate its use. At each step, there was increasing mirth, laughter, and hilarity, as the pantomime of heterosexual marriage unfolded in playful accuracy. Next was a brightly painted umbrella that was unfurled and placed over the groom. Pinned to its top was a profusion of bank notes and sweets. The money constituted a significant portion of the expenses of the event, and was referred to as ilobolo, bride wealth (cf. "cattle-without-legs," Comaroff and Comaroff 1990). The event concluded with the display of a large warm blanket (made in China), the most essential currency of any rural ceremony in South Africa, and the sharing of fizzy drinks substituting for home-brewed alcohol, umqombothi, a key symbol of domestic reproduction and ancestral authority. Within a few minutes, the plantation labourers were back on the trucks heading home. They called this event ukuqoma, "to accept," rendered in ordinary speech as intombi uyaqoma insizwa, "a girl accepts a young man."16 Talking to Nomvula a few weeks later, she described this event as wayemgaxa: "the stage of covering the girlfriend with a blanket." 17 Her description two days later was instructive:

\begin{abstract}
Well, I saw this (practice) and I wanted to tell the girl that I love her. It is just a game. It's like we are friends, in actual fact. Very close friends. If I have a problem I can tell her, and she can solve it for me; she also tells me if she has a problem. In order to show how close friends we are, she has even been to this house. They even know her in this house. The day she accepted my love proposal she gave me a plate and a tray to show that now I can say that I now have a very close friend. Then afterwards I have to make a function (ceremony) like the one that we did. In actual fact if you like, you can do it at home. Seeing that at home it wastes a lot of money because you have to cook (for everyone), I thought it was better to do it there (in the cross-roads). That wasn't the end. We also have to get married (to each other) in the end.
\end{abstract}

When Nomvula first started working in the forests, in 2004, she was approached by some of the women asking if she would accept to be engaged to them. She refused, not wanting to be intombi/young woman, and waited to see how the game worked. A year later she decided to approach another woman, as insizwa/young man herself. The burdens of intombi are too many (paying visits, doing laundry, cleaning, and other chores), although Nomvula had not made Zifikile do these things. For his part, an insizwa should treat his intombi with small gifts, perhaps food, clothing, accessories, or roses.

Initiating a relationship is difficult because it takes time to save up enough money to pay for all the necessary elements of the ritual, and to continue with the requisite gifts and mutual support. When pressed about the costs, Nomvula admitted that it was not really about the money as such, but the significance of the ritual event for their relationship and for their families: "It's just a (good old) wedding, but it's not the kind of thing you do at home, because, well, at home, there are the 'people under the earth' you see? We believe in the ancestors. ${ }^{18}$ What would they think we are doing? So we usually do at a school or in the road."

To proceed through the various stages of the marriage process, Nomvula had to be very careful: on the one hand, not to anger amadlozi (ancestors) by holding the ritual inside the yard; on the other hand, Nomvula had to ask permission from the elders in her home in a respectful manner because it would have quite an impact on their finances. It took a long time to get all these affairs in order, not only because of the permission she sought from her family, but also because of the expense involved in holding the wedding. For example, at the cross-roads that day, in the event named wayemgaxa, it was the critical gesture of placing a necklace (ucu) 
around her neck that needed to be performed (emgaxa) - requiring thereby the purchase of the necklace itself, drinks, sweets, gifts, blankets - and arranging for the teams to take time out on their way home. If they were to get "properly" married, she would have to ask permission all over again. While her umam'omncane was delighted by the whole idea of umshado wokudlala, her girlfriend's parents were not, and they refused to allow Nomvula to visit the yard.

The next step for the two women as a couple is umshado/marriage. Doke and colleagues $(1991,730)$ suggest that in early colonial translations, -shada was reserved for civil or Christian marriage, as distinct from "native custom." The stitching together of custom and civil rites in umshado wokudlala creatively shifts the alignments of jural, legal, and affective domains underlying the supposed unity of gender and kinship. In that event, the couple would combine umbongo and umshado, but it was unlikely to happen soon, she said, because it was expensive (the total cost of ukugaxa was around R800; in 2009 around US \$100, \$63 in 2015). One can communicate to one's partner the upper limit on how much should be spent on the occasion. Zifikile was spotted by her family members leaving home with all the dishes, washbasins and other small things for the ceremony, so they told her that they were expecting her to come back with at least as much value in return gifts. It took her two months to save for the event (R400 each month). In addition to these gifts, the umkhwenyana/young man is responsible for buying a case of drinks and cake. He is supposed to buy a suitcase filled with clothes, shoes, and so on, but as it turned out, Nomvula was afraid that she would buy the wrong things, and thus gave Zifikele the money to get whatever she liked. She was also supposed to buy a pillow and icansi ${ }^{19}$ (the ubiquitous traditional reed mat), which she promised she would get soon. She had written out a list of people in Zifikile's family and the gifts required for them; Nomvula, in turn, received enough dishes (and other gifts) for each of the members of her family, even for her little boy, "just like in an actual wedding." The relationship was founded on her admiration for Zifikile, and the fact that they were jealous of each other's male partners, and feared the seductions of other women, gave the game a quality of seriousness for Nomvula: "What can I say? I really love her. I'd be so offended if I found out that there is someone else and they love each other, and if she has chosen them I'd be so upset" (Laughter).

For Valentine's Day, Nomvula had bought her intombi a Valentine's cup with flowers on it, but had not yet received anything. She takes care of the plastic rose in a clear packet that Zifikile bought her last year, which hangs on the dresser by the bed. The exchange of these romantic gifts was accompanied by expressions of love, and they had kissed. Nomvula's family had enjoyed the expression of love they saw in the gift she was giving to Zifikile, and remarked on it to her.

Over the course of fieldwork in the plantations, I became friendly with Shumi who is a transport driver for Njojo contractors. He is the partner of S'mangele, Nomvula's sister, and he had begun payments for ilobolo for her. They had one child together. Towards the end of the fieldwork, in response to my interest in the marriages between women, he "proposed" to me. We would joke about it whenever we saw each other and he would dance in front of me, to make the women laugh. We began to make plans to hold some kind of event before I left Mtubatuba, but I left without having done anything about it.

One day, while chatting to Nomvula about the bridewealth and various family relations, she told us about the cattle that Shumi had paid for S'mangele, and that they were in Manguzi, up in the north, with her mother's brother. I jokingly asked her, "What if he paid that to me instead because he asked me to marry him? What do you think about men in the forest marrying each other?" Nomvula replied, "They're just fooling around, they are not really doing it. Anyway the others don't accept it. Shumi says that Nxumalo guy [a fellow plantation labourer] is his girlfriend, but Nxumalo scolds him (when he says that)."

Shumi regards Nomvula's "girl" (intombi) as a friend; when I asked Nomvula what Shumi says to Zifikile, she took this to mean "what does he call her" - as in, what term of address does he use with respect to her. "He says, "umnakwa"" - here she used the stem, which 
Zulu-English dictionaries give as "sister or brother-in-law." It is always used possessively, deictically locating the speaker and listener, for example, my brother-in-law, umnakwethu, his brother-in-law, umnakwabo. ${ }^{20}$

Nomvula's comments revealed the sensitivity of kin terms to contextual arrangements of speakers and addressees, and the range of kin implicated in the "game." I take up these implications below following the accounts of Thembisile and Thabisa that complicated the "nonserious" aspects of the game. In following the registers in which the making of meaning of kinship is performed, a different kind of grammar began to emerge.

\section{Second event}

The second example comes from the end-of-year function in December 2009, hosted by the silviculture contractor Baba Njojo for his employees, about 120 women and men. On this occasion, three couples were performing different stages of the marriage process of umshado wokudlala, using the opportunity presented by their employer's function to stage the event. Njojo himself was using the occasion of a ritual for his mother to throw a party for his employees to thank them for the year's work. Contrary to other contractors, especially in harvesting operations, he had built a reputation for treating his employees well.

Njojo's mother had passed away in 1981 but the family needed to have her marriage completed in order for the patrilineal ancestors to accept the next generation of wives marrying into the lineage. The weave of the three events thus entailed a complex braiding of generations, gestures, utterances, and relations that together constituted a dense series of laminations and metadiscursive signs, pointing to shifting conditions and conceptions of marriage and lineage as well as to the materials available for nurturing employees and kin. Baba Njojo described the ritual event for his deceased mother as ukukhunga, meaning to tie up, tether, or hang, specifically in reference to the gall bladder of a beast sacrificed in intercession with the ancestors. The semiotic mediations of ukukhunga bring bile (inyongo from the gall bladder), communication with the shades, and gift exchange into close relation. The giving of a gift, in this case a cow from Njojo's matriline in oPondweni to the deceased mother's sons for ritual slaughter, was part of the occasion, and its importance to ideas of vitality, health, and kinship cannot be overstated (see Cousins 2014).

This concatenation of events, each with its associated set of recognisable gestures, utterances, and sequences, is not an uncommon feature of ritual (cf. White 2004). Thus the constitutive elements of the context that day resonated between several different registers of "ritual." Here I focus on the last of these "events," the marriage ceremonies between the women, although I do not mean to imply that they occurred last temporally. The women's marriages were concluded before the party itself began for the forest labourers, whose general presence and participation in the meal and festivities constituted the conclusion of the ritual event for Baba Njojo's mother. The ukukhunga ritual had started the day before as per custom: the brewing of traditional beer, umqombothi, and slaughter of a beast, which had been left to hang overnight.

While the slaughtered meat was being prepared, the three couples made their own preparations in the open grass beyond the yard. They arranged their piles of gifts and drinks with enough space between them. The bride's parties established themselves to the left of the main entrance of Njojo's yard, the groom's to the right, mirroring the arrangement of men and women in the garages waiting for the feast (cf. Fernandez 1982; White 2010). The ceremony for the first couple, Nosipho and Nolwazi, proceeded similarly to that of Nomvula and Zikifile above: dancing, presentation and display of gifts to insizwa, including kitchen utensils, icansi, blanket, and towel for wayemgaxa. The next couple, Senzeni and Nana, began similarly. After the gift giving, Senzeni, as insizwa, lay down on the mat (icansi) for her bride to cover her with new pink bath towels, as large, beautiful printed yellow fabrics were spread around them as a screen, marking off a symbolic bedroom in which the couple lay together and kissed. 
The third couple, Fundiswa and Bongani, had arranged the gifts to be distributed, this time from the groom to the bride in an act of giving thanks (ukubonga, vt; umbongo, $\mathrm{n}$. cf Bryant 1949, 542). The groom's party approached in a line from the right carrying crates of fizzy drinks, and bags of clothes and linen, this time singing to the bride and her family, with the young men who had recently married leading the party. Fundiswa was seated, lady-like, under a bright red sun-umbrella, on the top of which were sweets, money (several hundred Rands in large denominations), and a facecloth. The various young men of the groom's party unpacked the bags of gifts and displayed each item; this time, cloth and clothing including underwear, towels, blouses, headscarves and pinafores (vital attire for proper, respectable women), skirts, jackets, shoes, umbrellas and several large soft blankets, in addition to curtains, doilies, wash cloths, grass mats and cosmetics (cf. Burke 1996). All of this was accompanied by the continuous singing and dancing characteristic of heterosexual customary marriage events.

The group then retreated from the midday sun to the shade of the twin garages adjacent to Njojo's house, wherein the categories "men" and "women" assumed their conventional designations and any questions about who were izinsizwa or izintombi were left aside.

\section{Serious and play gifts}

I turn next to Thembisile's reflections on her own experience of umshado wokudlala and her descriptions of the marriage process she had recently completed with the father of her children (the more "serious" wedding process). She explained that she had been unable to take the stages of umshado wokudlala any further than the initial "acceptance" (ukuqoma) because she had not yet completed the customary marriage process with Gazu, her children's genitor. She could not be seen to be trifling with a game, wasting precious income and savings, when the more serious business of securing her children's inclusion in their father's lineage was at stake. The laughter that accompanied our conversations, and Thembisile's insistence that to play this game was to suffer a form of madness, was echoed in all my conversations with women labourers on the topic: to play this game is a wasteful, useless, non-productive expenditure. "I should be making things right for my children so that when they want to get married it will not be said that their mother is not yet married. Yeyi! It is like the money that you have taken and thrown up in the air you see? You will see this if you really think about it carefully." As for those women who do spend large amounts of money in the game, Thembisile was scathing: a frivolous waste of money, a neglect of more serious domestic obligations, a fruitless investment, when one should be building one's own house. Not having secured one's hetero-marriage, she said, left one vulnerable in the event of the death of the father of one's children.

Several decades and many children later, Gazu had still not completed his bridewealth payments and it was only under duress, and with money borrowed from Thembisile, that he was finally able to settle the gifts to her family that constituted the finalisation of their marriage. Since he had presented several cattle over the years, and two head were outstanding, they agreed that the final gifts would be those of izibizo. ${ }^{21}$ The izibizo refers both to the institutional moment in which counter-gifts are specified and presented, and to the objects themselves, iconically given as the large three-legged pot that the mother of the departing bride uses to cook with on the day her daughter leaves for her husband's house. What remained were domestic goods ${ }^{22}$ for Gazu to give to Thembisile's family, and hers to give to his. ${ }^{23}$ This circulation of gifts and the events named after them provide the material substrate for umshado wokudlala amongst the women in the plantations.

As much as she was scathing about the irrationality of the expenditure, Thembisile was also enthusiastic about the competitive aspect of showing off how well one could display one's generosity. The basic sense of the performance is captured well in her description:

On the day when the gifts of thanks ${ }^{24}$ are handed out - that's when real stuff happens, my child. That's when I would take a suitcase and buy my girlfriend things from head to toe. I 
would also buy her mother a blanket, a scarf and a pinafore. Then I would buy a cake and some drink, and have a performance ${ }^{25}$ there at work. We would ask everyone, 'please stop and watch, today we're having umbongo.' We do it right there in the middle of the road. They turn off the trucks and then we come out with all the things; everything is there for ukwembesa. ${ }^{26}$ It's just like we do it normally at home. We put the gifts down in the middle. The older $\operatorname{sister}^{27}$ of the bride then distributes the gifts-that-cover.

In the extension of gifts from the pair to other (genealogically recognised) kin, the splendour of the generosity of each of the events is transformed, introducing a slippage between pure gift and self-interested investment. Thembisile described umshado wokudlala as both a game and a stokvel ${ }^{28}$ or informal savings group. The slippage is marked by anxiety about its performance and the sense of trust between the participants. The investments of money and time are, after all, substantial. According to custom, insizwa's sons, i.e. Thembisile's two sons still in high school, should reciprocate with gifts to their father's wife - in this case, their mother's intombi. Thembisile did so on their behalf by slowly accumulating gifts bought with the help of their government Child Support Grant (CSG), so that she could give them to her various izintombi over alternating months.

The scarves and blankets that Thembisile bought are worth more than what izintombi have given for her, constituting a generosity explicitly countering the cheapened reciprocity currently at work in the game. A range of feelings and intimacies are engendered by these gifts: Thembisile spoke of "making it very beautiful" when partners help each other complete work tasks in the plantation; and of disclosing one's problems and anxieties, sharing secrets and advice. There was also a great deal of jealousy between women when their partners appeared to be flirting (ukushela) with others, sometimes causing relationships to break up.

Apart from the straightforward use of intombi and insizwa for the principals, other kin terms were used to index the mobility of other relations. Thembisile, for example, would sometimes call her intombi "the mother of my children" or just her first name, Zodwa. On other occasions they might call each other by their clan name/isibongo. ${ }^{29}$ Zodwa often responded to Thembisile's terms of address with "father," baba. Her son's girlfriends called her mamezala ${ }^{30}$ out of respect, and she in turn addressed them as omakoti or with their isibongo, such as Ma Mkhwanazi. Gazu was amused by these terms, and addressed Thembisile's women as umnakwethu/our sister-in-law, ${ }^{31}$ indicating a relation of respect and intimacy. He helped her when she was buying the various gifts, cakes and drinks for the umbongo event described above. Gazu supported the game in the plantations where he worked and encouraged his wife as insizwa.

The words, objects, gestures, and feelings in circulation in umshado wokudlala suggest that property and value are co-implicated in the bending of the meanings of marriage, sex, and kinship. The investments of time, energy, and money in the game show that the relations at stake were not inconsequential, despite the women's protestations that they were not "serious." The set of banal and minor material objects that circulated through the ritual point to other scenes of significance: the gifted "dowry," as elements of the processual events, included domestic items such as plates, wash basins, and mats; a "trousseau" of face cloths, blankets, fabrics, towels, and clothes; toothbrush, paste, earrings, deodorant; and umbrellas on which were pinned the cash that has long been central to the great transformations of southern African life. As these objects circulate through the performances of the marriage events, they destabilise notions of dowry and bride wealth as they form surprising alliances between umbrellas and blankets, gumboots and protective gear, lunchtime sweets, transport trucks and crossroads. The networks of value they enliven, and the very bodies they are attached to, point to a series of exchanges and substitutions between the "game" and its serious counterpart. 


\section{Ama-tomboys}

Thabisa's comments on the game are instructive in light of her own sexual identity as a "tomboy." For Thabisa, there was nothing playful about umshado wokudlala: "At work, they think of this thing as a game. But as for me, I'm serious. I'm a tomboy. When I say I love a person, it's not a joke, I'm serious. A problem arises when you have to visit a person (at home). Obviously when you visit a person, things get messed up." There were other "tomboys" in the plantations, but none were as open about their sexuality. She was tough on her girlfriends about being exclusive, while maintaining her right to have other girlfriends. In telling us about the woman she was most serious about, Thabisa described the way in which her girlfriend, TK, was simultaneously "playing" when in the plantation (for the benefit of the other labourers), but "serious" when alone with Thabisa. TK's boyfriend, a man named Zeb, was not aware that she was in a sexual relationship with Thabisa. The game in the plantations provided a cover for their more "serious" relationship. Over the Christmas break that year, he had begun to suspect their sexual involvement, leading to a confrontation in which Zeb had accused Thabisa of being nkonkoni ${ }^{32}-$ a local slur for homosexuals.

While Thabisa was openly "out" as a tomboy in the plantations and at home, TK did not identify as a tomboy, but as a "female" (owesifazane). Thabisa presents herself as an accomplished lover, bragging about how much sexual pleasure she gives women, how many girlfriends she has, and how physically violent she can be, as a mirror of local Zulu masculinities. When I asked what a "tomboy" was, her response was to show us a small photoalbum in which she was posing in men's clothes in various urban holiday locations on the KwaZulu-Natal coast, with her arms wrapped around women in short skirts. To be a tomboy, she explained, is the same as nkonkoni, a term with similar valence as the more widely circulating insult isitabane. ${ }^{33}$ These are heavily pejorative terms, to which tomboy (pl: ama-tomboys) is a counter.

Despite a strong taboo on open homosexuality in this region, Thabisa thought that most people in her area were aware of gay and lesbian identities (cf. Epprecht 2008; Reid 2013). Thabisa talked about "really getting married," but she didn't see the need for registering the marriage with the Department of Home Affairs. She would rather do a "normal wedding," she said, one in which a priest from the locality officiated, because she had no interest in any of the events or stages of umshado wokudlala in the plantations. If they were to marry (ukushadisa), they would each be doing different types of things: "What can I say? We'd be doing the real thing. (Laughter). What else? She would be doing the work thing and also doing what she has to do for me." While Thabisa had not contributed to umshado wokudlala, TK, on the other hand, had given her ukubambisa gifts. Next would follow the stages of ukugaxa" and ukubonga. "We haven't planned that yet. We'll have to wait and see because we have had a few break-ups recently but maybe (that will happen)."

Not everyone who participates in umshado wokudlala wants to be involved physically, Thabisa pointed out. In a revealing reference to the terms of the "game" described by Judith Gay among high school girls in Lesotho, Thabisa suggested that,

I suppose some people just like to say, 'Oh I have a mother. ${ }^{35}$ For instance, maybe one of them likes to come to work in the morning and greet their partner, 'Hi mamo.' You see? And the other one is $u b a b a$ [father]. Then they would phone each other, just to say 'How are you mama,' or 'You know mamo bought me a surprise, babo bought me a surprise.' They just like playing such games. It's like a stokvel. They're just showing off. 'Oh my friend you see, babo did this for me. Please come and see. Oh they're so nice!' They just say these things. Even though you didn't ask, you'd hear from them all about it. Maybe one of them has a girlfriend but she doesn't buy anything for her, and you as a girl you also don't buy anything, so you're both the same, you're just mud. You have no story, you're just wasting time. 


\section{Context(s) as sign(s)}

The events of umshado wokudlala, and the investments, jealousies and laughter that they elicited, raise a number of questions about how proxemics, mutual aid, intimacy, and care are coordinated in everyday struggles of making-do. The capacity to locate these relations both spatially and temporally is as much a problem of naming, and of coming into knowledge of, the conventions, forces, attractions, and possibilities of marriage and desire (cf. Cavell 1979, 180), as it is a seemingly straightforward question of time and space. The material here suggests that the moments in which the relations articulated around and through the "game" cohere not because of the repetition of idealised structures or taken-for-granted terms of address or role inhabitation. Rather, it is that the tender and careful arrangements of kin terms, desires, and material objects help to bend the meanings of sex, gender, and kinship towards a minor form of "the otherwise" (cf. Povinelli 2006).

Reflecting on the various elements in recomposition, particular features stand out: shaping the body to indicate (a play with) gender (sitting, lying, dancing); the in-between spaces of performance; gestures such as tying the necklace, presenting the gifts, sitting together on icansi/grass mat; singing wedding songs from wife-giving family to those receiving; and material objects (blankets, plates, money pinned to the umbrella). Understanding these referents would thus seem a straightforward question of placing signs within a context, for example the history of the state (and its antecedents in precolonial modes of authority) and its concern for the family (e.g. Guy 1982). A critical rendering of such a history would note the presence of a certain ethnographic tradition that busied itself with a "collection of lists of words and phrases" (Gilmour 2006, 19) ${ }^{36}$ alongside naturalised accounts of landscape and social relations (Nuttall 1996), as if they were so many data points, providing a functionality of comparison and persuasion that might stabilise claims about the proper ordering of languages and people. To some extent, the genre cannot avoid it. To situate the women's accounts within a "context" is thus to invoke, involuntarily, the genres and fields of relations in which ethnographic accounts of "Zulu marriage" have been produced.

If the contemporary terrain of labour, desire, and social reproduction were merely the "product" of history, in what terms could one provide an acceptable account of its inventiveness and improvisational qualities? Distinguishing clearly between text and context, or figure and ground, becomes, as Silverstein (1997) suggests, a matter of tracking both the presuppositions indexed in communicative events and their entailments, or uptake. Which elements or terms of a "context" might constitute a "system of terminology" and which a "system of affection" (LeviStrauss 1970) is not given beforehand, in some structurally determinative sense, and how they come to be available for use in language-in-action can not be assumed either (Silverstein and Urban 1996). Rather, they have to be learned in particular contexts, as Cavell $(1979,170)$ points out, the appropriateness of which is betrayed after the fact of their usage, in the forms of life that emerge with such grammars.

I take Levi-Strauss's understanding of kinship as a system of signs shaped by a grammar to be an invitation to consider how kin terms and the affections they index might be hinged in a metapragmatic operation residing in a ritualised, playful form. Between the constraints of a system of signs (tethered in some necessary fashion to their objects, cf. Benveniste 1971) and the circulation of diffuse, non-institutionalised attitudes, how are we to consider the creativity of umshado wokudlala? The ritual performances of umshado wokudlala demonstrate how the pragmatics of constituting care, intimacy, and relatedness around the timber plantations both shaped and were shaped by the metapragmatic function of kin terms - that is, the uses to which kin terms were put to index shifting material conditions and webs of meaning. The rituals, gestures and utterances of the women who caught on to the game in the timber plantations thus revealed how relations are constituted and gain expression in ways that embrace the contingent, dynamic, and flexible terms engendered by late liberalism. In parsing out the relations between a system of grammar, in Levi-Strauss's sense, and the affections or attitudes that emerge from 
language-in-use, we can see how kin terms index the shifting conditions from which their systematicity emerges. Yanagisako and Collier's claim that gender and kinship constitute a unified field comes under strain when their respective systems produce alternative arrangements of gender, sex, and relatedness. Indeed, the distinction itself between "play" and "serious," as it emerges from the utterances and performances of the actors, is destabilised and becomes a matter of fluidity and invention in its practice.

\section{Conclusion}

As Yanagisako and Collier (1987) pointed out, distinguishing between gender and sex obscures the way in which concepts like "man" or "woman" are themselves premised on a folk-cultural matrix of ideas about biology and reproduction. They argued that the only way to overcome the residue of biology in feminist critiques of gender and kinship was to treat them as a unified whole arising out of practices of meaning making by specific actors in particular places. Such an analysis, they argued, would account for the ways in which systems of gender, kinship, and sex arise together in ways that produce inequality or violence. I have taken issue here with the notion that gender, kinship, and sex conform to a consistent grammar, or produce predictable meanings or practices. Between a system of terminology (of kin terms) and a system of institutionalised attitudes (such as respect or familiarity) we can see how feelings, expressions, objects, and places, can be rearranged and realigned to bend the meanings and possibilities of kinship to other ends.

The words and worlds of the women labouring in the timber plantations are weighted by the histories and possibilities for constituting relations in this particular terrain. However tracing the contours of those histories and possibilities reveals some sense of the risks and provisionalities entered into and sustained by umshado wokudlala. As the events of, and commentaries on, umshado wokudlala show, language-in-action puts at risk the meanings of terms like "boyfriend"/"girlfriend," or insizwalintombi that are often assumed to be stable and consistent. Not only are kin terms destabilised, but concepts of "man" or "woman" that supposedly secure their meaning in one way or another also come into question. It is not simply that sex, gender, and kinship do not arise together in any necessary way, but also that words may be grafted onto various configurations of intimacy so that participants may "relax" into existing orders of meaning (Povinelli 2001). For example, when Thabisa says that her girlfriend tells others in the plantation that they are together, the meanings of insizwa and intombi are braced by the terms of umshado wokudlala - which thus saves them from homophobic violence (Gunkel 2013). In addition, the "game" provides a shelter for whatever meanings and sexualities they bring to their private lives so that Thabisa can say, "when she is with me, it's serious." Thus the system "serious/play" provides a structure that braces the meanings of kinship, gender, and sex against the radical shifts in material conditions in which domestic economies, production and reproduction are arranged. Thus it may appear that the "game" is more playful and less serious than heterosexual marriage, raising the possibility that this play, as play, re-inscribes the more typical and normative architecture of sex-gender-kinship sign systems. However, such a claim would rest on an appeal to a picture of typicality and normativity which themselves are put into circulation here.

Finding a language for the risks and provisionalities expressed in umshado wokudlala and its articulation with the material substrate of life around the plantations is a challenge (cf. Povinelli 2001, 404-5). If anthropology understands kin terms to be laminated onto systems of gender, kinship, and sex, it is because it is the dominant mode through which it understands life. The modalities of comprehending obligation, relatedness and reproduction undergo a degree of what Levi-Strauss $(1970,153)$ called "torsion" in the practices and utterances of the game's participants, and that securing their meanings and referents is a much trickier affair than many accounts of marriage would have us believe. 


\section{Notes on contributor}

Thomas Cousins is a South African medical anthropologist with particular interests in health, labour, kinship, and science studies. He teaches in the Department of Sociology and Social Anthropology at Stellenbosch University. His fieldwork examines the intersections of nutrition and sanitation, the body, politics, and public health. 


\section{Notes}

1. iLobolo was a scandal for colonial administrators and missionaries because it appeared to reduce women to currency or payment in a market transaction (Kuper 1982).

2. For example, The Recognition of Customary Marriages Act of 1998, see Herbst and du Plessis 2008; Bennett 2009.

3. Gluckman $(1950,182)$ : "The Zulu in Natal have the same types of marriage-forming families as are reported by Evans-Pritchard from the Nuer in the far distant Sudan."

4. Hunter's (2010) re-reading of romantic love in KwaZulu-Natal would suggest a different understanding of emotions and sanctions surrounding sexuality, marriage, and reproduction.

5. It is important to note that "law" here is taken as aspect of indigenous institutional social life, and not as a construction of colonial codification.

6. Gluckman $(1950,184)$ : "Therefore men who are dead or impotent, and women, all physically incapable of begetting, can be paters of children who have been begotten by other men, and a whole group can be pater to children whose mother's marriage-cattle it has contributed."

7. Gluckman (1950, 185): "If they do the latter [return cattle for a barren woman], a good Zulu does not necessarily send his barren wife home; he may use the returned marriagecattle to obtain a wife whom he puts 'into the house' of his barren wife to bear children for her. Thus even maternity can be fictitious."

8. See also Mark Hunter (2010) and Paul Landau (2010) who interrogate histories of sexuality and the invention of tribalism, respectively, and reflect on the ways in which the people governed by these English terms navigated the violent translations of custom and practice.

9. The shift away from migrancy to encouraging labourers to live next to the mines or plantations has come into question again after the Marikana tragedy of August 2012. Keith Breckenridge (2012) has suggested that this dubious shift in housing policy was premised on Monica Wilson's criticism of the apartheid state's policy of enforced labour migration that exhausted a fund of social capital "of a very strong African family system" (Wilson, quoted in Breckenridge).

10. To accept or to choose. Ukuqoma forms one crucial stage of the long process of customary marriage, the timing of which I discuss in detail below.

11. All names have been changed to protect identities.

12. Here biologically sexed males, but the difficulty of maintaining referential consistency in ethnographic description of precisely to the point - see Povinelli (2001) for a brilliant exposition.

13. Women should cover their head and not wear trousers to conform to the image of a respectful woman.

14. What happens when the gendered and sexed norms of referentiality are displaced or inverted, such that it is bio-men who must carry the mark of qualification, contra "man" as human?

15. Into which she peered while she went through the motions. This is a semiotically complex moment in which she was no longer simply insizwa, but also a woman, miming the gestures of feminine beautification.

16. Mark Hunter (2010) translates ukuqoma as "to choose" for when a woman responded favourably to a proposal from a man (139). The different kinds of action at stake (to choose versus to accept) were not apparent to me at the time, but the encoding of relative positions of action and passivity would need to be explored in relation to the specific histories of practice concerning marriage and custom between the localities and circumstances in which these terms were used. Thus, an older grammar in which young 
women do the choosing and young men are chosen is caught in the expression. In the game in the plantations, a similar grammar is evident: the young men do the courting (bayashela, they burn with desire for the young women, who in turn choose). Ukuqoma is in the active voice, while the passive voice is ukuqonywa.

17. Doke et al. (1991, 233): 1. Place across, let hang over, put astride, hook on, tie around. Cloth, blankets, clothes, were all vital elements of various gifts exchanges during heterosexual, customary marriage processes, along with other bedroom and kitchen utensils and accoutrements, including a chest in which to store the fabric. Cf. discussions of trousseau in Olsen's (1989) comments on Tambiah et al. (1989) Also Laubscher 1937, 169.)

18. Abantu abaphansi and amadlozi respectively. The drift in meaning of terms for "ancestor" is entangled in the history of the encounter of Christianity with African concepts of spirit, and the contours of the politics of translation. See Brain, Ruel, and Kopytoff (1982) for a history of the debate on ancestors in Africa, and for more recent argumentation, see Landau (2010) and White (2001).

19. According to the dictates of respect (ukuhlonipha), the visiting young man should not sit on the girl's bed, but rather sit and sleep on this mat. Nomvula had no issue with this herself though. It is merely the form borrowed from the real wedding process.

20. The plural forms operate in the same manner as the $\mathrm{T} / \mathrm{V}$ form of etiquette, except that the possessives operate by explicitly, i.e. normatively or ideologically, locating the individual within groups - "our" and "their" - cf. Agha 2004, 38).

21. Doke et al $(1991,80)$ : "Article claimed as part of ilobolo or as compensation. Imvulamlomo isibizo sesilisa (something given to open up negotiations is what is demanded by the males).

22. Impahla yasendlini - Doke et al. $(1991,509)$ give "good" (as in a tradable object) for impahla, but in isiXhosa izimpahla are clothes - hence the close association that seems apparent between goods, clothes, and the notion of "trousseau."

23. Ukwembesa abantu balayikhaya. Sometimes, the two families ask for each other's lists to assess the equivalence of gifts to be exchanged. In her case, her brother's illness has delayed the preparations, as he would be the one to buy the gifts for her wedding as the oldest man in the family.

24. Umbongo, from the infinitive ukubonga, to thank. The ordering of gift exchanges is explained below.

25. Umsebenzi - performance/ceremony/ritual - cf. the "work" of ritual.

26. The nounal verb is ukwembesa: Doke et al. $(1991,185)$ give: to clothe or cover with a blanket, cloak etc. That part of the ceremony in which gifts of blankets and clothes are distributed to appropriate family members.

27. Iqhikiza lentombi: The girl's older female family member - it is she who distributes the gifts. In the game, this is another labourer who plays the role of iqhikiza.

28. "This is a game. It is like a stokvel game. If you are my intombi I will make you happy by buying you stuff, and give it to you. And you also do the same and say 'I am buying for my man'." Stokvels are clubs or syndicates serving as rotating credit unions in South Africa where members contribute fixed sums of money to a central fund on a weekly, fortnightly or monthly basis. Cf. Collins et al. (2009) and Verhoef (2001).

29. The slippage between "clan" name and "surname" is driven by the history of the state's identification systems, specifically the apartheid dompas (pass book) and post-apartheid Identity Book, which is crucial for accessing welfare.

30. Doke et al. (1991, 386): -Zala. 1. Verb: ukuzala. Bear, give birth, beget, generate. 2. N. Suffix, indicating relation by marriage. Umamezala (my mother-in-law). 
31. Doke et al. (1991, 506): -mna-formative indicating intimate friendship or relationship, used in compound: umna kwethu my brother/sister-in-law [the plural form -ethu operating as $\mathrm{T} / \mathrm{V}$ marker of respect].

32. Literally, wildebeest. Mmina ngiyinkonkoni what what. "That I am a wildebeest and so on."

33. In common parlance, a derogatory term for lesbians, from an older time, give: -tabane (umtabane, imitabane): vaginal belt of soft grass worn during menstruation.

34. To cover (the shoulders) with a blanket.

35. Note the entanglement of debt and savings in stokvel and the figure of the parent.

36. "The collection of lists of words and phrases had been, for centuries, a common ingredient in Western ethnographic writing" (Gilmour 2006, 19).

\section{References}

Agha, A. 2004. "Registers of Language." In A Companion to Linguistic Anthropology, edited by A. Duranti, 23-45. Oxford: Blackwell Publishing.

Agha, A. 2007. Language and Social Relations: Studies in the Social and Cultural Foundations of Language. Cambridge, UK: Cambridge University Press.

Bennett, T. 2009. "Re-introducing African Customary Law to the South African Legal System." The American Journal of Comparative Law 57 (L. 1).

Benveniste, E. 1971. Problems in General Linguistics. Miami, FL: University of Miami Press.

Blacking, J. 1959. "Fictitious Kinship Amongst Girls of the Venda of the Northern Transvaal." Man 59 (8): 155-158.

Blacking, J. 1978. "Uses of the Kinship Idiom in Friendships at Some Venda and Zulu Schools." In Social System and Tradition in Southern Africa, edited by J. Argyle and E. PrestonWhyte, 101-117. New York: Oxford University Press.

Boellstorff, T., and N. N. Dave. 2015. "Introduction: The Production and Reproduction of Queer Anthropology." Fieldsights - Theorizing the Contemporary, Cultural Anthropology Online, July 21, 2015. http://www.culanth.org/fieldsights/708-introduction-theproduction-and-reproduction-of-queer-anthropology.

Brain, J. L., M. T. Ruel, and I. Kopytoff. 1982. "The Authority of Ancestors." Man (New Series) 17 (3): 546-548.

Breckenridge, K. 2012. "Revenge of the Commons: The Crisis in the South African Mining Industry." History Workshop Online, November 5, 2012. http://www.historyworkshop.org.uk/revenge-of-the-commons-the-crisis-in-the-southafrican-mining-industry/.

Bryant, A. T. 1949. The Zulu People. Pietetmaritzburg, SA: Shuter and Shooter.

Burke, T. 1996. Lifebuoy Men, Lux Women: Commodification, Consumption, and Cleanliness in Modern Zimbabwe. Durham, NC: Duke University Press.

Carrier, J., and S. O. Murray. 1998. "Women-Women Marriage in Africa." In Boy-Wives and Female Husbands: Studies of African Homosexualities, edited by S. Murray and W. Roscoe, 255-266. New York: St Martin's Press.

Cavell, S. 1979. The Claim of Reason: Wittgenstein, Skepticism, Morality, and Tragedy. New York: Oxford University Press.

Collins, D., J. Murdoch, S. Rutherford, and O. Ruthven. 2009. Portfolios of the Poor: How the World's Poor Live on \$2 a Day. Princeton: Princeton University Press.

Comaroff, J. L., and J. Comaroff. 1990. "Goodly Beasts, Beastly Goods: Cattle and Commodities in a South African Context." American Ethnologist 17 (2): 195-216. 
Cousins, T. 2014. "Knowledge of Life: Health, Strength and Labour in KwaZulu-Natal, South Africa." Anthropology Southern Africa 37 (1-2): 30-41.

Doke, C. M., D. M. Malcolm, J. M. A Sikakana, and B. W. Vilakazi. 1991. English - Zulu, Zulu - English Dictionary. Johannesburg, SA: Witwatersrand University Press.

Epprecht, M. 2008. Heterosexual Africa? The History of an Idea from the Age of Exploration to the Age of AIDS. Athens, OH: Ohio University Press.

Fernandez, J. 1982. Bwiti: An Ethnography of the Religious Imagination in Africa. Princeton, NJ: Princeton University Press.

Gay, J. 1986. "'Mummies and Babies' and Friends and Lovers in Lesotho." Journal of Homosexuality 11 (3-4): 97-116.

Gilmour, R. 2006. Grammars of Colonialism: Representing Languages in Colonial South Africa. New York: Palgrave Macmillan.

Gluckman, M. 1950. "Kinship and Marriage Among the Lozi of Northern Rhodesia and the Zulu of Natal." In African Systems of Kinship and Marriage, edited by A. R. Radcliffe-Brown and D. Forde, 166-206. London: Oxford University Press.

Gunkel, H. 2013. "Some Reflections on Postcolonial Homophobia, Local Interventions, and LGBTI Solidarity Online: The Politics of Global Petitions." African Studies Review 56 (02): 67-81.

Guy, J. 1982. "The Destruction and Reconstruction of Zulu Society." In Industrialisation and Social Change in South Africa: African Class, Culture, and Consciousness, 1870-1930, edited by S. Marks and R. Rathbone, 167-194. New York: Longman Inc.

Herbst, M., and W. du Plessis. 2008. "Customary Law v Common Law Marriages: A Hybrid Approach in South Africa." Electronic Journal of Comparative Law 12 (1). http://www.ejcl.org/121/art121-28.pdf.

Hunter, M. 2010. Love in the Time of AIDS: Inequality, Gender, and Rights in South Africa. Bloomington, IN: Indiana University Press.

Kuper, A. 1982. Wives for Cattle: Bridewealth and Marriage in Southern Africa. Boston, MA: Routledge and Kegan Paul.

Landau, P. S. 2010. Popular Politics in the History of South Africa, 1400-1948. Cambridge, UK: Cambridge University Press.

Laubscher, J. F. 1937. Sex, Custom and Psychopathology: A Study of South African Pagan Natives. London: Routledge.

Levi-Strauss, C. 1970. The Savage Mind. Chicago, IL: University of Chicago Press.

McClendon, T. 2010. White Chief, Black Lords: Shepstone and the Colonial State in Natal, South Africa, 1845-1878, Rochester Studies in Africa and the Diaspora. Rochester, NY: University of Rochester Press.

McCormick, T.-L. 2015. "A Critical Engagement? Analysing Same-Sex Marriage Discourses in To Have and to Hold: The Making of Same-Sex Marriage in South Africa (2008) - A Queer Perspective." Stellenbosch Papers in Linguistics Plus 46: 99-120.

Milani, T. M. 2015. "Language, Gender and Sexuality in South Africa." Stellenbosch Papers in Linguistics Plus 46: i-v. doi:10.5842/46-0-672.

Msibi, T., and S. Rudwick. 2015. "Intersections of Two isiZulu Genderlects and the Construction of 'Skesana' Identities." Stellenbosch Papers in Linguistics Plus 46: 51-66. doi:10.5842/46-0-616.

Nuttall, S. 1996. "Flatness and Fantasy: Representations of the Land in Two Recent South African Novels." In Text, Theory, Space: Post-Colonial Representations and Identity, edited by K. Darian-Smith, L. Gunner, and S. Nuttall, 215-226. London: Routledge.

O'Brien, D. 1977. "Female Husbands in Southern Bantu Societies." In Sexual Stratification: A Cross-Cultural View, edited by A. Schlegel, 109-126. New York: Columbia University Press. 
Oboler, R. S. 1980. "Is the Female Husband a Man? Woman/woman Marriage among the Nandi of Kenya." Ethnology 19 (1): 69-88.

Oslon, E. 1989. "Comment on S. Tambiah's Bridewealth and Dowry Revisited: The Position of Women in Sub-Saharan Africa and North India. Current Anthropology 30 (4): 413-435.

Pons-Vignon, N., and W. Anseeuw. 2009. "Great Expectations: Working Conditions in South Africa since the End of Apartheid." Journal of Southern African Studies 35 (4): 883-899.

Povinelli, E. A. 2001. "Sexualty at Risk: Psychoanalysis Metapragmatically". In Homosexuality and Psychoanalysis, edited by T. Deane and C. Lane, 387-411. Chicago: University of Chicago Press.

Povinelli, E. A. 2006. The Empire of Love: Toward a Theory of Intimacy, Genealogy, and Carnality. Durham, NC: Duke University Press

Povinelli, E. A. 2011. Economies of Abandonment: Social Belonging and Endurance in Late Liberalism. Durham, NC: Duke University Press.

Radcliffe-Brown, A. R. and D. Forde. 1950. African Systems of Kinship and Marriage. Oxford, UK: Oxford University Press.

Reid, G. C. 2013. How to Be a Real Gay: Gay Identities in Small-Town South Africa. Scottsville, SA: University of KwaZulu-Natal Press.

Rubin, G. 1975. "The Traffic in Women: Notes on the Political Economy of Sex." In Toward an Anthropology of Women, edited by R. R. Reiter, 157-210. New York: Monthly Review Press.

Schneider, D. M. 1968. American Kinship: A Cultural Account. Chicago, IL: University of Chicago Press.

Silverstein, M. 1993. "Metapragmatic Discourse and Metapragmatic Function." Reflexive Language: Reported Speech and Metapragmatics. Cambridge, UK: Cambridge University Press.

Silverstein, M. 1997. "The Improvisational Performance of Culture in Realtime Discursive Practice." In Creativity in Performance, edited by R. K. Sawyer, 32-58. New York: Cambridge University Press.

Silverstein, M. 2003. "Indexical Order and the Dialectics of Sociolinguistic Life." Language \& Communication 23 (3): 193-229.

Silverstein, M., and G. Urban. 1996. Natural Histories of Discourse. Chicago, IL: University of Chicago Press.

Tambiah, S. J., M. Goheen, A. Gottlieb, J. I. Guyer, E. A. Olson, C. Piot, K. W. van der Veen, and T. Vuyk. 1989. "Bridewealth and Dowry Revisited: The Position of Women in SubSaharan Africa and North India [and Comments and Reply]." Current Anthropology 30 (4): 413-435.

Urban, G. 2001. Metaculture: How Culture Moves Through the World. Minneapolis, MN: University of Minnesota Press.

Verhoef, G. 2001. "Informal Financial Service Institutions for Survival: African Women and Stokvels in Urban South Africa, 1930-1988." Enterprise and Society 2 (2): 259-296.

White, H. 2001. "Tempora et mores: Family Values and the Possessions of a Post-Apartheid Countryside". Journal of Religion in Africa XXXI (4).

White, H. 2004. "Ritual Haunts: The Timing of Estrangement in a Post-Apartheid Countryside." In Producing African Futures: Ritual and Reproduction in a Neoliberal Age, edited by B. Weiss, 141-166. Leiden: Koninklijke Brill NV.

White, H. 2010. "Outside the Dwelling of Culture: Estrangement and Difference in Postcolonial Zululand." Anthropological Quarterly 83 (3): 497-518.

Yanagisako, S. and J. Collier. 1987. Gender and Kinship: Essays Toward a Unified Analysis. 1st ed. Stanford, CA: Stanford University Press. 